\title{
Assessment of Wetland Water Quality and Avian Diversity of a Human-Modified Floodplain Wetland on River Yamuna
}

\author{
Upma MANRAL ${ }^{1 *}$, Faiyaz A. KHUDSAR² \\ ${ }^{1}$ Wildlife Institute of India, Chandrabani, Dehradun-248001, Post Box 18, India; upmamanral2@gmail.com (*corresponding author) \\ ${ }^{2}$ Yamuna Biodiversity Park, Centre for Environmental Management of Degraded Ecosystems, University of Delhi, Delhi-110007, India
}

\begin{abstract}
Okhla Bird Sanctuary (OBS) is an Important Bird Area, which comes under the protected area network of Uttar Pradesh with one-third area lying in the state of Delhi (India). OBS has widest flood plains along the Delhi stretch of river Yamuna and is important in conserving the ecological wealth of floodplains of the river. Rapid urbanization and industrialization and discharge of untreated wastewater into the river have resulted in deteriorated water quality. The present study focused on assessment of water quality, aquatic flora and avifaunal diversity in the OBS. Water quality was analyzed following methods of APHA. For vegetation analysis, sub-merged and free-floating plants were scooped up from five randomly selected sites. Total bird counts were conducted for water birds and species richness, evenness and Shannon-Weaver species diversity indices were calculated. Results indicate that the organic load is very high in the wetland as evident from low levels of dissolved oxygen $(2.26 \pm 1.62 \mathrm{mg} / \mathrm{l})$ and high Biological and Chemical Oxygen Demands (15.20 $\pm 3.75 \mathrm{mg} / \mathrm{l}, 44.60 \pm 12.07 \mathrm{mg} / \mathrm{l})$. Nine species of free-floating and submerged plants were recorded; Hydrilla verticillata, Vallisneria spiralis, Azolla pinnata and Ceratophyllum demersum dominated both deep and shallow water areas. 52 species of waterbirds including four near-threatened species viz., Anhinga melanogaster, Mycteria leucocephala, Threskiornis melanocephalus and Aythya nyroca were recorded. OBS provides opportunities for conservation in a metropolitan area, thus, appropriate measures should be taken to maintain its ecological integrity.
\end{abstract}

Keywords: aquatic flora, macrophytes, okhla bird sanctuary, organic load, water birds

\section{Introduction}

Wetlands are 'areas of marsh, fen, peatland or water, whether natural or artificial, permanent or temporary with water that is static or flowing, fresh, brackish or salt, including areas of marine water, the depth of which at low tide does not exceed six meters' (Ramsar Convention, 1971). Wetlands are often considered as 'hot spots' of biodiversity within a region or a landscape (Gopal and Sah, 1993) and are unique communities which involve a diversity of plants and animals, many of which are adapted to shallow and often dynamic water regimes (Weller, 1999). Wetlands are important bird habitats and birds use them for nesting, breeding, roosting, and rearing young ones and for feeding, resting, shelter and social interaction (Stewart, 2001). With the intensification of human activities causing environmental changes, wetlands are subjected to heavy pressure (Turner et al., 2000) and threats (Mitsch and Gossenlink, 2000). Encroachment of wetland habitat, unsustainable harvesting of resources, industrial pollution, poisoning, agricultural runoff, siltation and introduction of exotic and invasive species put wetland biodiversity under threat (Baral and Inskipp, 2005; Kafle et al., 2008). This has severe consequences on water bird populations, leading to change in community structure of birds and population declines (Kloskowski et al., 2009). India, with its varied topography and climatic regimes support and sustain diverse and unique wetland habitats. Besides natural wetlands, man-made wetlands also contribute to the ecological wealth of the country and provide a number of ecological services. There are 67,429 wetlands in India, covering 4.1 million hectare area, out of these 2,175 are natural and rest are man-made, mangroves cover an additional 6,740 sq km area (Ramachandra, 2001). It is estimated that freshwater wetlands alone support $20 \%$ of the known range of biodiversity in India (Deepa and Ramachandra, 1999). The Okhla Bird Sanctuary (OBS) in Noida is one such example with 302 bird species and $14,000-20,000$ waterbirds recorded from the Sanctuary and its surrounding areas (Urfi, 2003). The wetland is facing threats because of rapid urbanization and pollution despite providing an example of conservation management of wetland amidst densely populated city.

Present study look into the status of water quality, submerged and free-floating plant communities and species diversity of birds that would be helpful in monitoring the course of changes in future. 
26

\section{Materials and methods}

\section{Study area}

The study was conducted in Okhla Bird Sanctuary (Fig. 1), an 'Important Bird Area' (Kohli, 2006) and a man modified flood plain wetland on river Yamuna (India). Construction of the Okhla barrage across the river Yamuna has converted a small portion of the river into a static water system. In May 1990, the lake created because of barrage on the river and surrounded flood plains were notified as OBS by the Uttar Pradesh government under the Wildlife (Protection) Act, 1972 of India. Geographically, the sanctuary is located between latitudes $28^{\circ} 32^{\prime} 44^{\prime \prime} \mathrm{N}$ and $28^{\circ} 34^{\prime} 18^{\prime \prime} \mathrm{N}$ and longitudes $77^{\circ} 17^{\prime} 41^{\prime \prime} \mathrm{E}$ and $77^{\circ} 19^{\prime} 12^{\prime \prime} \mathrm{E}$. The floodplains of Yamuna in Delhi are restricted between lateral bunds with maximum width of active floodplains observed in and around OBS. This results in a mosaic of habitats supporting diversity of life. The wintering ducks at Okhla are dependent upon the surrounding areas, especially the grassy patches, agricultural fields and marshes around the barrage for feeding (Urfi, 2003). The pollution load in the stretch between Wazirabad and Okhla barrages is highest along the $1,170 \mathrm{~km}$ stretch of the Yamuna through the Indo-Gangetic plains (Gopal and Sah, 1993). Despite heavy pollution and human interventions, Okhla Bird Sanctuary provides habitat for a number of species of birds, reptiles, mammals and amphibians (Urfi, 2003).

The study area was visited in different seasons during 2008-2009 and field data was collected regularly from January to April 2009 on the following parameters:

\section{Water sample collection and water quality analysis}

Sites were divided into deep water $(\geq 1.5 \mathrm{~m})$ and shallow water $(<1.5 \mathrm{~m})$ areas. Estimation of depth was done using a well-marked bamboo pole. Random grab water samples were collected in triplicate in polyethylene bottles during morning hours from the midstream ( $1 / 2$ width of river) and from the well mixed zone at depth of 0.3 meters at five sites. Utmost care was taken to avoid spilling of water and air bubbling at the time of sample collection. Readings for $\mathrm{pH}$, temperature and conductivity were taken at the site with digital meters. Samples were preserved and analyzed in the laboratory using standard methods for the analysis of water and waste water prescribed by APHA (2005). Values for cations of calcium, magnesium, iron and manganese in water were estimated using Ion Chromatography technique.

\section{Vegetation sampling}

Henderson and Crampton's (1997) circular hand net of a $30 \mathrm{~cm}$ diameter mouth was used by modifying it to scoop up sub-merged vegetation in five randomly selected sites (area that is likely to represent the vegetation assemblage of the whole community) (Van Geest et al., 2005). Emergent and floating plant species which came along with sub-merged species were also recorded. Total numbers of individuals of each species were counted. Areas highly infested by Echhornia crassipes and Alternanthera spp. were avoided.

\section{Waterbird count}

To estimate the population of aquatic birds, total counts were carried out every fortnight for four months from the shore and each census lasted for 4 to 6 hours (Bibby et al., 2000; Vijayan, 1991). Species richness, evenness and Shannon-Weaver species diversity indices were calculated (Shannon and Weaver, 1949) to find out the community structure of birds in the area. The status of birds (resident or migratory) was given from Ali and Ripley (1972) and Urfi (2003).

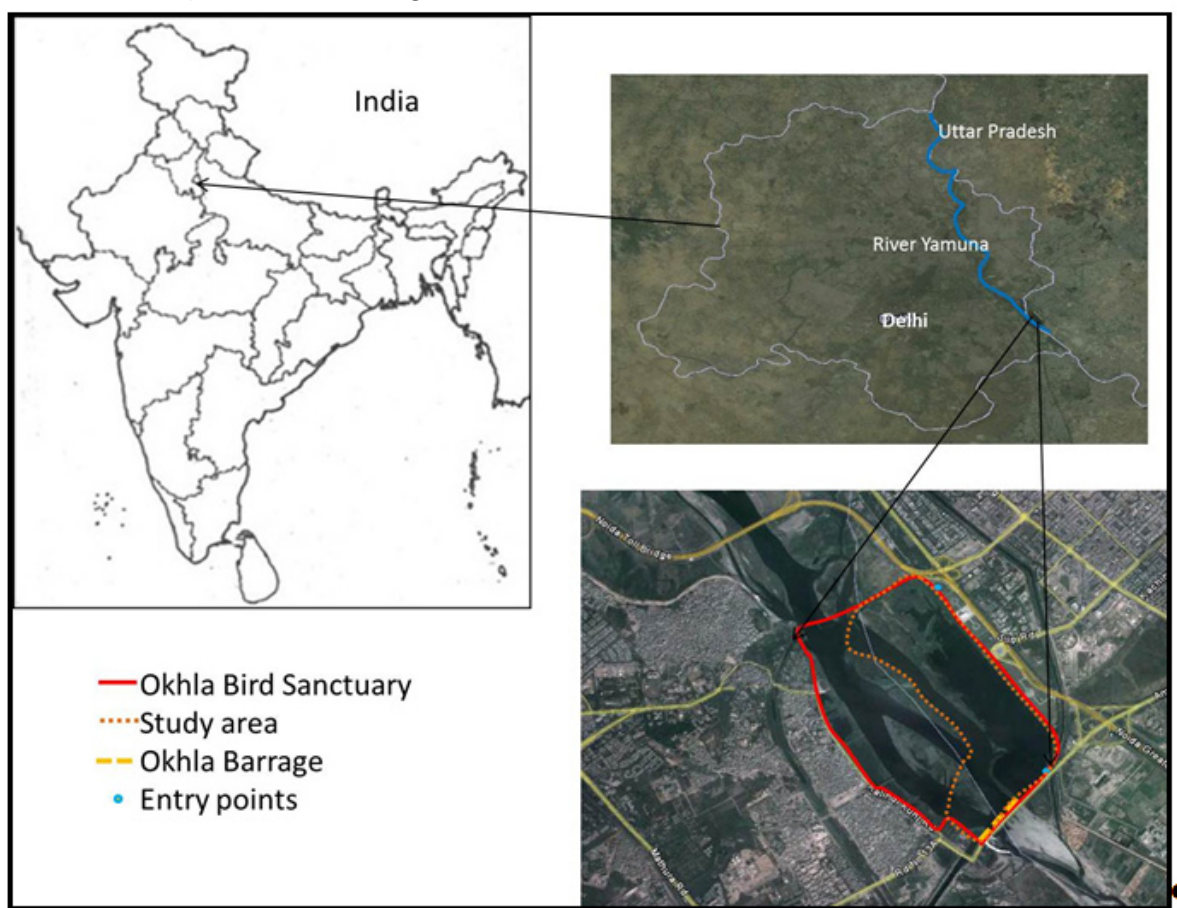

Fig. 1. Map of Okhla Bird Sanctuary, a point where River Yamuna enters the state of Uttar Pradesh from Delhi (India) 


\section{Results}

\section{Physio-chemical characters and nutrient content of the} river

Data collected on the physical and chemical characters and nutrient contents with their average values for each sites (deep and shallower areas) are presented in Tab. 1 . The temperature values ranged from $26.93 \pm 1.07^{\circ} \mathrm{C}$ (mean \pm standard deviation) for shallower sites to $21.75 \pm 0.64^{\circ} \mathrm{C}$ for deeper sites. Water in all the sites was slightly alkaline with values ranging from $7.5 \pm 0.06$ (shallower sites) to 7.5 \pm 0.14 (deeper sites). The average value for $\mathrm{pH}$ was $7.5 \pm$ 0.09 . Average value for electrical conductivity was 507.25 $\pm 166.10 \mu \mathrm{S}$. All the sites had dissolved oxygen (DO) less than required limit of $4 \mathrm{mg} / \mathrm{l}$ or more given by Central Pollution Control Board of India (CPCB, 2008) for propagation of wildlife in river water. The average value of $\mathrm{DO}$ for river water was $2.26 \pm 1.62 \mathrm{mg} / \mathrm{l}$. The biological oxygen demand was $13.40 \pm 1.70 \mathrm{mg} / \mathrm{l}$ (deeper sites) to $16.40 \pm$ $4.61 \mathrm{mg} / 1$ (shallower sites) with an average value of 15.20 $\pm 3.75 \mathrm{mg} / \mathrm{l}$ for river water and the average value of chemical oxygen demand for river water was $44.60 \pm 12.07 \mathrm{mg} / \mathrm{l}$ with a relatively higher value for deeper sites $(54 \pm 8.49$ $\mathrm{mg} / \mathrm{l})$. The average values for various nutrients were 0.64 $\pm 0.13 \mathrm{mg} / \mathrm{l}$ for phosphates, $271.52 \pm 57.49 \mathrm{mg} / \mathrm{l}$ for chloride, $8.46 \pm 3.85 \mathrm{mg} / \mathrm{l}$ for nitrates, $50.88 \pm 27.23 \mathrm{mg} / \mathrm{l}$ for sulfate, and $1.21 \pm 1$ for potassium ions. The low value of $\mathrm{DO}$ and high values of BOD, COD, nitrates etc. indicate organic pollution in the water.

\section{Status of emergent, floating and sub-merged vegetation}

A total of nine aquatic plant species from eight families were recorded in the water of the OBS (Tab. 2). Out of these, four species were submerged, three were free floating, one was emergent and one species showed both submerged and emergent behavior. Species richness was high- er in shallow water sites ( 9 species) while it was recorded 4 to 5 in deep water sites (Tab. 3). Ceratophyllum demersum had the highest density at both the deep (864.03 \pm 80.12 individual $\left.\mathrm{m}^{-2}\right)$ as well as shallow water $(377.71 \pm 654.22$ individual $\mathrm{m}^{-2}$ ) sites. Average density for Ceratophyllum demersum was $572.24 \pm 535.31$ individuals $\mathrm{m}^{-2}$. The surrounding terrestrial and semi-aquatic vegetation observed during the study in the immediate surroundings of shallow sites included Xanthium strumarium, Commelina spp., Eclipta alba, Ipomoea fistulosa, Euphorbia spp., Achyranthus aspera, Polygonum spp., Centella asiatica, Ageratum conyzoides, Phragmites karka, Saccharum bengalensis, Typha angustifolia, Arundo donax, Carex alopecuroides and Cyperus spp. etc.

\section{Avian diversity}

Fifty-two species of birds belonging to fourteen families (Tab. 4) were recorded during the study. Anatidae was the richest family represented by 13 species (24\%) followed by Ardeidae and Charadriidae (6 species in each), Rallidae ( 5 species), Laridae (4 species). Phalacrocoracidae, Threskiornithidae, and Motacillidae were represented by 3 species each, 2 species each belonged to Ciconidae, Jacanidae and Hirundinidae families and 1 species each belonged to Podicipedia, Phoenicopteridae, Alcedinidae and Accipitridae families. 24 species were residents and 27 were winter migrants, of which 2 species were local migrants while two were passage migrants and one species viz. Glossy ibis's population was resident with few migrating individuals (Tab. 4). The most abundant species among waterfowl was Anas clypeata contributing about $46 \%$ to the total waterfowl population followed by Anas acuta (14\%) and Aythya fuligula (10\%). Four species viz., Anhinga melanogaster, Mycteria leucocephala, Threskiornis melanocephalus and Aythya nyroca are listed as near threatened in IUCN Red-data list (IUCN Red list, 2012).

Tab. 1. Values (mean \pm standard deviation) for different water quality parameters in Okhla Bird Sanctuary, Uttar Pradesh

\begin{tabular}{cccc}
\hline Parameter/ Site & Deep $(\geq 1.5 \mathrm{~m})$ & Shallow $(<1.5 \mathrm{~m})$ & Overall \\
\hline $\mathrm{pH}$ & $7.5 \pm 0.14$ & $7.5 \pm 0.06$ & $7.5 \pm 0.09$ \\
\hline Conductivity, $\mu \mathrm{S}$ & $595 \pm 210$ & $419.50 \pm 86.97$ & $507.25 \pm 166.10$ \\
\hline Temperature, ${ }^{\circ} \mathrm{C}$ & $21.75 \pm 0.64$ & $26.93 \pm 1.07$ & $24.86 \pm 2.96$ \\
\hline BOD, $\mathrm{mg} / \mathrm{l}$ & $13.40 \pm 1.70$ & $16.40 \pm 4.61$ & $15.20 \pm 3.75$ \\
COD, $\mathrm{mg} / \mathrm{l}$ & $54 \pm 8.49$ & $38.33 \pm 10.41$ & $44.60 \pm 12.07$ \\
\hline Alkalinity, ppm & 200 & $160 \pm 30.41$ & $176 \pm 30.70$ \\
\hline Phosphate, $\mathrm{ppm}$ & $0.74 \pm 0.06$ & $0.57 \pm 0.12$ & $0.64 \pm 0.13$ \\
\hline Chloride, ppm & $251.15 \pm 1.77$ & $195.10 \pm 68.73$ & $217.52 \pm 57.49$ \\
\hline Nitrate, ppm & $8.12 \pm 6.18$ & $8.68 \pm 3.22$ & $8.46 \pm 3.85$ \\
\hline Sulfate, $p$ pm & $68.70 \pm 42.43$ & $39 \pm 7.3$ & $50.88 \pm 27.23$ \\
\hline Calcium, ppm & $5.20 \pm 1.10$ & $6.86 \pm 0.31$ & $6.20 \pm 1.09$ \\
\hline Ammonium, ppm & $5.20 \pm 1.48$ & $9.16 \pm 0.45$ & $7.57 \pm 2.31$ \\
\hline Potassium, ppm & $0.29 \pm 0.41$ & $1.82 \pm 0.72$ & $1.21 \pm 1$ \\
\hline Magnesium, ppm & $21.74 \pm 0.97$ & $22.24 \pm 2.01$ & $22.04 \pm 1.53$ \\
\hline Sodium, ppm & $21.49 \pm 1.35$ & $27.73 \pm 2.32$ & $25.23 \pm 3.85$ \\
\hline
\end{tabular}


28

Tab. 2. Sub-merged and free-floating plant species during present study

\begin{tabular}{|c|c|c|}
\hline Family & Habit & Plant species \\
\hline \multirow{2}{*}{ Hydrocharitaceae } & Sub-merged & Hydrilla verticillata (L.f.) Royle \\
\hline & Sub-merged & Vallisneria spiralis $\mathrm{L}$. \\
\hline Ceratophyllaceae & Sub-merged & Ceratophyllum demersum $\mathrm{L}$. \\
\hline Azollaceae & Free-floating & Azolla pinnata R. Br. \\
\hline Araceae & Free-floating & Lemna minor $\mathrm{L}$ \\
\hline Onagraceae & Emergent & Ludwigia adscendens (L.) H. Hara \\
\hline Potamogetonaceae & Sub-merged & Potamogeton crispus $\mathrm{L}$. \\
\hline Rannunculaceae & $\begin{array}{l}\text { Emergent/ } \\
\text { sub-merged }\end{array}$ & Ranunculus aquatilis $\mathrm{L}$. \\
\hline Pontederiaceae & Free-floating & Echhornia crassipes Solms \\
\hline
\end{tabular}

The birds began departing from the last week of Fabruary. Geese were not reported in the month of March and numbers of waterfowl also declined from previous months. However, Aythya nyroca (Ferruginous Pochard) and Anas querquedula (Gargeny) were recorded in the month of March only as both are passage migrants in the area. Anas clypeata (Northern Shovelers) were the last migrants to leave and a small number was recorded in April. Bird species richness was highest in the month of March showing an increase from January to March but showed a sharp decrease in the month of April (Fig. 2, Tab. 5). This is because the sanctuary is located in the Central Asian
Flyway of migratory birds and thousands of birds use it as a wintering ground as well as a stopover site. These migratory birds form a major part of waterfowl population of the wetland and as the summer approaches, these start flying back to their breeding grounds. Shannon-Weaver Index for diversity was highest for the month of April and showed an increase from January to April. This could be due to higher species evenness in the month of April. The higher evenness in the month of April could be due to departure of waterfowl species which dominate the waterbird population during the migratory season (Fig. 2, Tab. 5).

\section{Discussion}

\section{Water quality}

The physio-chemical environment of water functions in many ways and employs the influences upon biotic components, thus, giving a picture of the environmental suitability of water to maintain life (Kumar and Singh, 2002). Temperature affects various chemical and biological reactions taking place in water and aquatic organisms (Shrivastava and Patil, 2002) and depends upon the season, time of sampling and also upon the temperature of effluent which is being added into the river. The mean temperature of river water in OBS was $24.86 \pm 2.96$ and was comparatively higher for the shallower sites in comparison to

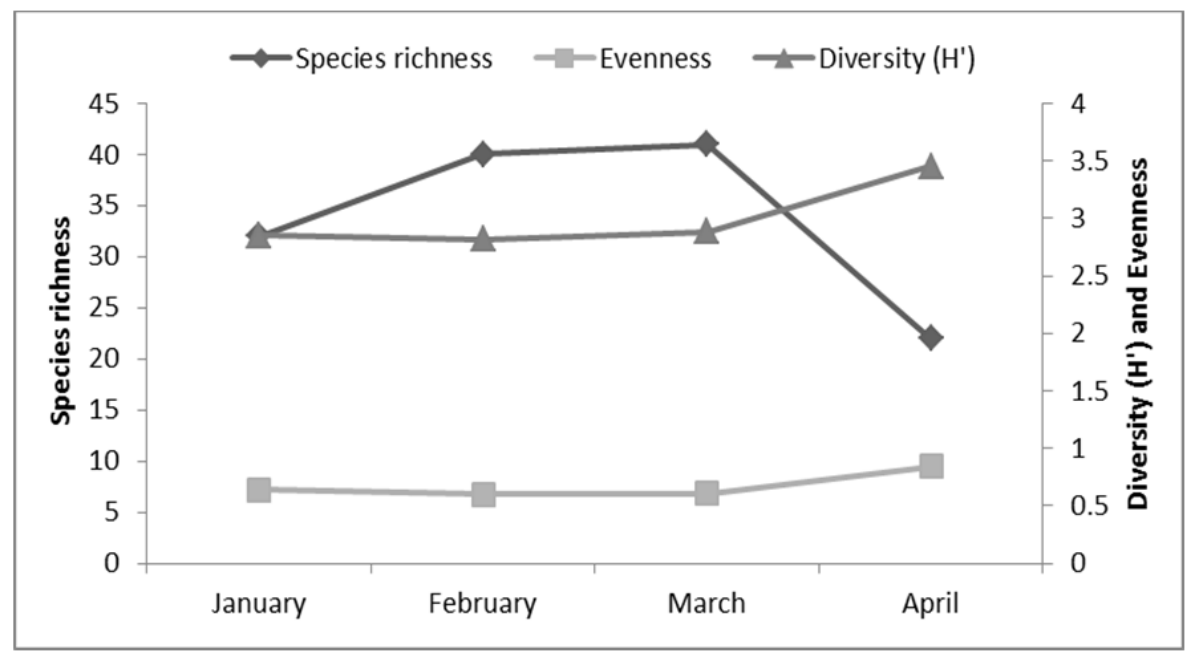

Fig. 2. Species richness, evenness and shannon-weaver diversity index for waterbirds

Tab. 3. Status of aquatic vegetation across various sampling sites

\begin{tabular}{cccc}
\hline Plant species/ Site & Deep $(\geq 1.5 \mathrm{~m})$ & Shallow $(<1.5 \mathrm{~m})$ & Overall \\
\hline Hydrilla verticillata & $198.24 \pm 20.12$ & $89.71 \pm 45.53$ & $133.12 \pm 68.35$ \\
Vallisneria spiralis & $127.48 \pm 20.03$ & $47.22 \pm 16.36$ & $79.32 \pm 46.55$ \\
Ceratophyllum demersum & $864.03 \pm 80.12$ & $377.71 \pm 654.22$ & $572.24 \pm 535.31$ \\
Azolla pinnata & $92.07 \pm 90.14$ & $240.79 \pm 64.91$ & $181.30 \pm 103.80$ \\
Lemna minor & 0 & $42.49 \pm 14.17$ & $25.50 \pm 25.34$ \\
Ludwigea adscendes & 0 & $33.05 \pm 8.18$ & $19.83 \pm 19$ \\
Potamogeton crispus & $369.32 \pm 522.30$ & $28.33 \pm 49.07$ & $164.73 \pm 322.93$ \\
Ranunculus aquatilis & 0 & $23.61 \pm 21.64$ & $14.16 \pm 20.03$ \\
Echhornia crassipes & 0 & $18.88 \pm 8.18$ & $11.33 \pm 11.85$ \\
\hline
\end{tabular}


Tab. 4. Waterbird species recorded during present study

\begin{tabular}{|c|c|c|c|c|}
\hline Order & Family & Common Name & Scientific Name & Status \\
\hline Podicipitiformes & Podicipedidae & Little Grebe & Tachybaptus ruficollis & $\mathrm{R}$ \\
\hline \multirow{3}{*}{ Pelecaniformes } & \multirow{3}{*}{ Phalacrocoracidae } & Darter* & Anhinga melanogaster & $\mathrm{R}$ \\
\hline & & Little Cormorant & Phalacrocorax niger & $\mathrm{R}$ \\
\hline & & Great Cormorant & Phalacrocorax carbo & LM \\
\hline \multirow{12}{*}{ Ciconiformes } & \multirow{6}{*}{ Ardeidae } & Little Egret & Egretta garzetta & $\mathrm{R}$ \\
\hline & & Intermediate Egret & Mesophoyx intermedia & $\mathrm{R}$ \\
\hline & & Cattle Egret & Bubulcus ibis & $\mathrm{R}$ \\
\hline & & Indian Pond Heron & Ardeola grayii & $\mathrm{R}$ \\
\hline & & Grey Heron & Ardea cinerea & $\mathrm{R}$ \\
\hline & & Purple Heron & Ardea purpurea & $\mathrm{R}$ \\
\hline & \multirow{2}{*}{ Ciconidae } & Painted Stork ${ }^{*}$ & Mycteria leucocephala & $\mathrm{R}$ \\
\hline & & Asian Openbill Stork & Anastomus oscitans & $\mathrm{R}$ \\
\hline & \multirow{3}{*}{ Threskiornithidae } & Black Headed Ibis* & Threskiornis melanocephalus & $\mathrm{R}$ \\
\hline & & Glossy Ibis & Plegadisfalcinellus & $\mathrm{R}, \mathrm{W}$ \\
\hline & & Black Ibis & Pseudibis papillosa & $\mathrm{R}$ \\
\hline & Phoenicopteridae & Greater Flamingo & Phoenicopterus roseus & LM \\
\hline \multirow{17}{*}{ Anseriformes } & \multirow{17}{*}{ Anatidae } & Greylag Goose & Anser anser & $\mathrm{W}$ \\
\hline & & Barheaded Goose & Anser indicus & W \\
\hline & & Ruddy Shelduck & Tadorna ferruginea & W \\
\hline & & Northern Pintail & Anas acuta & W \\
\hline & & Common Teal & Anas crecca & W \\
\hline & & Spotbill Duck & Anaspoecilorhyncha & $\mathrm{R}$ \\
\hline & & Gadwall & Anas strepera & W \\
\hline & & Eurasian Wigeon & Anaspenelope & W \\
\hline & & Garganey & Anas querquedula & PM \\
\hline & & Northern Shoveller & Anas clypeata & W \\
\hline & & Common Pochard & Aythya ferina & W \\
\hline & & Ferruginous Pochard* & Aythya nyroca & W \\
\hline & & Tufted Duck & Aythya fuligula & W \\
\hline & & Whitebreasted Waterhen & Amaurornis phoenicurus & $\mathrm{R}$ \\
\hline & & Common Moorhen & Gallinula chloropus indica & $\mathrm{R}$ \\
\hline & & Purple Swamphen & Porphyrio porphyrio poliocephalus & $\mathrm{R}$ \\
\hline & & Common Coot & Fulina atra atra & W \\
\hline \multirow{12}{*}{ Charadriiformes } & \multirow{2}{*}{ Jacanidae } & Pheasant-tailed Jacana & Hydrophasianus chirurgus & $\mathrm{R}$ \\
\hline & & Bronzewinged Jacana & Metopidiusindicus & $\mathrm{R}$ \\
\hline & \multirow{6}{*}{ Charadriidae } & White-tailed Lapwing & Vanellus leucurus & W \\
\hline & & Redwattled Lapwing & Vanellus indicus indicus & $\mathrm{R}$ \\
\hline & & Green Sandpiper & Tringa ochropus & W \\
\hline & & Wood Sandpiper & Tringa glaeora & W \\
\hline & & Ruff & Philomachuspugnax & W \\
\hline & & Indian Blackwinged Stilt & Himantopus himantopus & $\mathrm{R}$ \\
\hline & \multirow{4}{*}{ Laridae } & Blackheaded Gull & Larus ridibundus & W \\
\hline & & Brownheaded Gull & Larus brunnicephalus & W \\
\hline & & Pallas's Gull & Larusichthyaetus & W \\
\hline & & Indian River Tern & Sterna aurantia & $\mathrm{R}$ \\
\hline \multirow{5}{*}{ Passeriformes } & \multirow{3}{*}{ Motacillidae } & Citrine Wagtail & Motacilla citreola & W \\
\hline & & Yellow Wagtail & Motacilla flava & W \\
\hline & & Rosy Pipit & Anthus roseatus & W \\
\hline & \multirow{2}{*}{ Hirundinidae } & Barn Swallow & Hirundo rustica & W \\
\hline & & Wiretailed Swallow & Hirundo smithii & $\mathrm{R}$ \\
\hline Coraciiformes & Alcedinidae & White-throated Kingfisher & Halcyon smyrnensis & $\mathrm{R}$ \\
\hline Falconiformes & Accipitridae & Eurasian Marsh Harrier & Circus aeruginosus & W \\
\hline
\end{tabular}

R: Resident; W: Winter migrant; LM: Local migrant; PM: Passage migrant; *: Near threatened 
30

Tab. 5. Status of waterbirds across various months during present study

\begin{tabular}{ccccc}
\hline Parameter & January & February & March & April \\
\hline Species richness & 32 & 40 & 41 & 22 \\
Abundance & 3034 & 3336 & 2295 & 116 \\
Evenness & 0.64 & 0.6 & 0.61 & 0.84 \\
\hline Diversity $\left(\mathrm{H}^{\prime}\right)$ & 2.21 & 2.22 & 2.27 & 2.61 \\
\hline
\end{tabular}

deeper sites which could be due to dark muddy bottoms. Deep waters usually are colder because they require more time to warm up and sampling was done in the morning. However, temperature was lowest $\left(25.7^{\circ} \mathrm{C}\right)$ for one of the shallower sites that could be due to the presence of shade as this site was nearer to the left afflux bund of sanctuary that had overhanging trees. Water had an optimum $\mathrm{pH}$ range with an average value of $7.5 \pm 0.09$, which is suitable for the growth of aquatic biota (Ellis, 1937).

DO along with BOD and COD are important parameters in water quality assessment and indirect indicators of organic matter and industrial waste present in a waterbody (Brinley, 1942; Manahan, 1993; Tarzwell, 1957). Low levels of DO in the water indicate stress problem for aquatic organisms and in a healthy lotic ecosystem the level of DO is generally close to saturation (7 mg/l) (Manahan, 1993). The low content of DO $(2.62 \pm 1.62 \mathrm{mg} / \mathrm{l})$ in the sanctuary water might be due to the high oxygen consumption by oxidisable matter present in the water coming in along with the domestic sewage (Brinley, 1942; Das and Sinha, 1993; Manahan, 1993; Tarzwell, 1957). DO levels are considered as one of the limiting factors for wetland ecosystem and can have large effects on chemical and biological processes in the system (Heimann and Femmer, 1998; Tarzwell, 1957). The oxygen depletion not only affects biotic community of the river but also affects its self-purification capacity. In Delhi stretch, the load of organic matter is so high that it consumes the entire dissolved oxygen available in river water $(\mathrm{CPCB}, 2006)$. High values of both $\mathrm{BOD}$ and COD indicate high levels of organic pollution in the river water. Sivasubramanium (1999) attributed higher levels of BOD (8.2- $35.2 \mathrm{mg} / \mathrm{l})$ in few stretches of Periyar River to sewage pollution. The approximate COD/ BOD ratio for untreated domestic sewage is $>2$ (Mara, 1978) requiring biological treatment and other treatments if it's more (Rao and Dutta, 1979). In the present study, the average for this ratio was higher than 2 and was more than 3 for two sites (Tab. 1). This indicates presence of untreated sewage waste in the river water.

Both the nitrate and chloride are excellent parameters to judge the organic pollution in the water. Nitrate represents the highest oxidized form of nitrogen and the high levels of nitrate result due to decomposition of organic matter which gets transformed by aerobic and anaerobic bacteria into nitrogenous matter (Shrivastava and Patil, 2002). A nitrate concentration in excess of $0.3 \mathrm{mg} / \mathrm{l}$ may result in algal bloom (Raina et al., 1984). In all the sites, nitrate value was higher than this and resulted in algal bloom in the waterbody (Fig. 3). Both the chloride and sulfate values were higher than of natural fresh water but well below the permissible limit given by CPCB (for drinking water, $<250 \mathrm{mg} / \mathrm{l}$ and $200 \mathrm{mg} / \mathrm{l}$ respectively). However, as organic load is high in water, indicated from levels of other parameters, lower values of both chloride and sulfate could be due to interference of other compounds occurred while analyzing samples e.g. organic materials interfere with precipitation of Barium Sulfate in the 'Turbiditric method' (APHA, 2005) for estimating sulfate

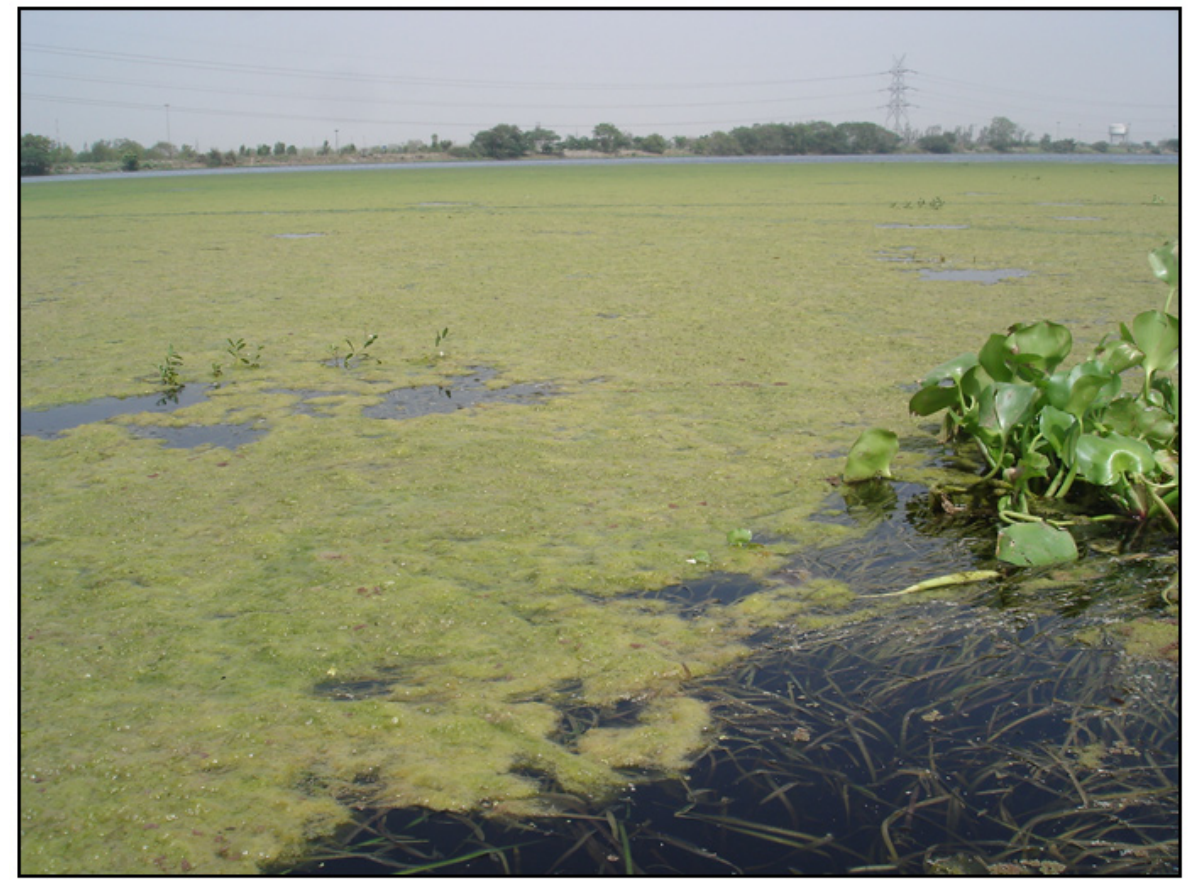

Fig. 3. Algal bloom and sub-merged vegetation community of the Sanctuary during present study 
concentration in water. In the natural waters phosphate is recorded at low levels of about $0.01 \mu \mathrm{g} / \mathrm{l}$ (Gupta, 2002). In the study area, phosphate levels were higher than the natural levels and resulted in algal bloom in the water. Sivasubramanium (1999) in Periyar River found higher phosphate (up to $0.25 \mathrm{mg} / \mathrm{l}$ ) along with high BOD. In a study of Tungabhadra River, Kulkarni (1997) found lower levels of phosphate in the upstream stretches compared to stretches receiving sewage and industrial effluents.

Cation of calcium, magnesium, iron and manganese contribute to the hardness of water (Shrivastava and $\mathrm{Pa}$ til, 2002). Calcium, one of the most abundant substances of natural water is also added along with sewage and industrial wastes. Sodium concentration in irrigation water and soil is of great interest as high sodium contents make soil hard to plough and unsuitable for seedling emergence. Yamuna water in the sanctuary had sodium concentration from $21.49 \pm 1.35 \mathrm{mg} / \mathrm{l}$ at deeper sites to $27.73 \pm 2.32$ $\mathrm{mg} / \mathrm{l}$ at shallower sites and potassium level from $0.29 \pm$ $0.41 \mathrm{mg} / \mathrm{l}$ at deeper sites to $1.82 \pm 0.72 \mathrm{mg} / \mathrm{l}$ at shallower sites, suggesting their moderate but harmless concentration. The high concentration of ammonium ions (7.57 \pm $2.31 \mathrm{mg} / \mathrm{l})$ in the water is also indicative of domestic sewage and industrial wastewater.

\section{Wetland ecology}

Aquatic plants directly or indirectly provide food, shelter and breeding sites to animals (Dvork and Best, 1982), support livelihood subsistence to humans living in the nearby areas (Banerjee et al., 2012; Irfanullah, 2002; Ghosh, 2005) and provide a botanical conservation index for waterbodies (Linton and Goulder, 2000). Diverse submerged plants within a waterbody form a number of microhabitats resulting in different assemblages of invertebrates providing them with shelter from predators (Dvork and Best, 1982; Linton and Goulder, 2000) and sites for attachment (Diehl, 1992; Rooke, 1986b). According to Chowdhury et al. (2008) aquatic macrophytes exhibit a feeding relationship with fishes while the number of bird species and their diversity is positively correlated with the richer vegetation covering the water surface (Andrikovics et al., 2006).

OBS, with its sub-merged and emergent macrophytic communities, provides food and habitat for many micro and macro fauna. Deep-water habitats were dominated by Ceratophyllum demersum, Hydrilla verticillata, Vallisneria spiralis and Azolla pinnata. Shallow water habitats had more species richness compared to deep-water habitats with addition of emergent species. This habitat had all the species recorded from OBS during present study with highest density shown by $C$. demersum, present only at one of the shallower sites followed by $A$. pinnata and $H$. verticillata. C. demersum is considered one of the 100 worst invasive species by the Invasive Species Specialist Group of the IUCN Species Survival Commission (2010). Squires and Anderson (1995) in a study on Trumpeter swan and
Paulus (1982) on Gadwall found that these birds avoid $C$. demersum. McGaha (1952) studied limnological relations of insects to certain aquatic flowering plants and found no species of insects on $C$. demersum, out of total 61 studied. However, Craven and Hunt (1984) found that $C$. demersum formed component of food in certain species of waterfowl. Other species viz., H. verticillata, L. minor, A. pinnata and P. crispus also provide food and shelter to many insects, fish and wetland bird species (Banerjee $e t$ al., 2012; Esler, 1989; Johnson and Montalbano, 1984; Judd, 1953; O'meara, 1982; Scotland, 1940).

Despite poor water quality, sanctuary had considerable numbers of wetland birds. The main reason could be presence of mosaic of habitats within the wetland environment. A lot of vegetation in and around the river and shallow water body provide food and shelter to birds like Tadorna ferruginea, Anas acuta, Anas crecca, Anas clypeata, Aythya ferina, Amaurornis phoenicurus, Fulina atra atra and Sterna aurantia. According to a study by Dunning et al. (1992) in the Donavana wetland complex, the overall capacity of a wetland complex to support bird populations may be increased when the landscape comprises habitat patches in close proximity. Relative availability of habitats for different activities has a major influence on the size of wintering populations (Andrikovics et al., 2006; Dunning et al., 1992). The sanctuary had extensive reed beds, shallow vegetated areas, and open deep waters. Submerged plant species viz. H. verticillata and $P$. crispus and free floating species viz. L. minor and A. pinnata provide food to herbivore waterfowl. Tall vegetation e.g. Phragmites carca and Typha angustifolia along the side in draw-down areas provide shelter to species viz. Anser indicus, Tadorna ferruginea, Ardea purpurea, Pseudibis papillosa, Mycteria leucocephala etc. Despite the poor quality of water, Anser indicus were recorded from the area. Security from predators and availability of food in adjacent areas could be the reason. Phalacrocorax carbo was also present but in less number, as they prefer cleaner waters with lots of fishes. Phoenicopterus roseus were also recorded in the area as the shallow waters in OBS provide the bird with food. Food in the form of organic matter ensures presence of gulls like Larus ridibundus and Larus ichthyaetus. This shows aquatic vegetation is very important for a wetland ecosystem as they can be a direct food for aquatic birds and for invertebrates and fishes that are food for birds.

\section{Conclusions}

Okhla Bird Sanctuary is located amidst the urban settlement and is a unique habitat providing opportunities for conservation in a metropolitan like Delhi; as a stopover for migratory water birds and home for several other taxa of fauna and flora. The site has been protected since 1990, under the Wildlife (Protection) Act, 1972, however the health of the sanctuary and the birds that make this their home is not ensured. Low DO and high BOD and 
32

COD values indicate high pollution load in the wetland. This coupled with high phosphate levels resulted in algal bloom in the area. However, observation period was limited to a short time frame and hence cannot be viewed as complete but it definitely provides an outline of wetland ecology of the area. There is an urgent need of proper management steps and studies in different seasons of the year for the conservation of this wetland, being a barrage, management of water level would also be ecologically important to maintain the more shallow water area. There is a need of detailed ecological studies to establish a relationship between the environmental changes due to human activities, changes in species composition of vegetation and declining bird diversity in the area.

\section{Acknowledgements}

We thank Prof. Mihir Deb, former director of School of Environmental Studies and Forest department staff at OBS for their support.

\section{References}

Ali S, Ripley SD (1972). Handbook of the Birds of India and Pakistan, vol. 1-9. Oxford University Press, Bombay, India, 2667 p.

Andrikovics S, Forro L, Gere G, Lakatos G, Sasvari L (2006). Water bird guilds and their feeding connections in the Bodrogköz (Northeast Hungary). Hydrobiologia 567:3142.

Banerjee S, Kar D, Banerjee A, Palit D (2012). Utilization of some Aquatic macrophytes in Borobandh: a lentic water body in Durgapur, West Bengal, India: Implications for socio-economic upliftment of local stakeholder. Indian J Appl Pure Biol 27(1):83-92

Baral HS, Inskipp C (2005). Important bird areas in Nepal: key sites for conservation. Bird Conservation Nepal and Birdlife International, Kathmandu and Cambridge, $242 \mathrm{p}$.

Bibby CJ, Burgess ND, Hill DA, Mustoe SH (2000). Bird Census Techniques. $2^{\text {nd }} \mathrm{ed}$. Academic Press, London, $302 \mathrm{p}$.

Brinley FJ (1942). Biological studies: Ohio River pollution survey 1 . Biological zones in a polluted stream. Sewage Works J 14:147-152.

Chowdhury MMR, Shahjahan M, Rahman MS, Sadiqul Islam M (2008). Duckweed (Lemna minor) as Supplementary Feed in Monoculture of Nile Tilapia, Oreochromis niloticus. J Fish Aquat Sci 3:54-59.

CPCB (2006). Water quality status of Yamuna River (19992005). Assessment and Development of River Basin Series: ADSORBS/41/2006-07. Central Pollution Control Board, Assessed from http://www.cpcb.nic.in/newitems/11.pdf on 25-1-2012.

CPCB (2008). Guidelines for water quality monitoring. Central Pollution Control Board, New Delhi. MINARS/27/2007-08, Accessed from http://www.cpcb.nic.
in/upload/NewItems/NewItem_116_Guidelinesof\%20waterqualitymonitoring_31.07.08.pdf on 25-2-2012.

Craven SR, Hunt RA (1984). Fall food habits of Canada Geese in Wisconsin. J Wildl Manage 48(1):169-173.

Das NK, Sinha RK (1993). Assessment of water quality of the Ganga River, Bihar, India. Environ Ecol Kalyani 11(4):829832.

Deepa RS, Ramachandra TV (1999). Impact of Urbanization in the interconnectivity of wetlands. Proc National Symposium on Remote Sensing Applications for Natural Resources: Retrospective and perspective, Indian Society of Remote Sensing, Bangalore.

Diehl S (1992). Fish predation and benthos community structure-the role of omnivory and habitat complexity. Ecology 73:1646-1661.

Dunning JB, Danielson JB, Pulliam HR (1992). Ecological processes that affect populations in complex landscapes. Oikos 65:169-175.

Dvork J, Best EPH (1982). Macro-invertebrate communities associated with the macrophytes of Lake Vechten: structural and functional relationships. Hydrobiologia 95:115-126.

Ellis MM (1937). Detection and measurement of stream pollution. United States Bureau of Fish Bulletin, Washington 22:367-437.

Esler D (1989). An assessment of American Coot herbivory of Hydrilla. J Wildl Manage 53:1147-1149.

Johnson FA, Montalbano III F (1984). Selection of plant communities by wintering waterfowl in Lake Okeechobee, Florida. J Wildl Manage 48:174-178.

Ghosh SK (2005). Illustrated aquatic and wetland plants in harmony with mankind. Standard Literature, India, $25 \mathrm{p}$.

Global Invasive Species Database (2010). Ceratophyllum demersum (aquatic plant). Electronic database available at http:// www.issg.org/database/species/ecology accessed on 19-12012.

Gopal B, Sah M (1993). Conservation and management of rivers in India: case study of the River Yamuna. Environ Conserv 20:243-254.

Gupta TRC (2002). Water quality of the rivers of Dakshina Kannada and Udupi districts, Karnataka, 69-85 p. In: Kumar A (Eds.). Ecology and conservation of lakes, reservoirs and rivers. ABD publishers, Jaipur, India.

Heimann DC, Femmer SR (1998). Water quality, hydrology and invertebrate communities of three remnant wetlands in Missouri, 1995-97. Water resources investigations report 98-4190, U.S. Geological Survey.

Henderson PA, Crampton WGR (1997). A comparison of fish diversity and abundance between nutrient rich and poor lakes in the upper Amazon. J Trop Ecol 13:175-198.

Irfanullah HM (2002). Studies on aquatic vascular plants in Bangladesh: an appraisal. Bangl J Plant Taxon 9(1):85-116.

IUCN Red list for Birds (2012). BirdLife International, Assessed from http://www.birdlife.org on 22-3-2012. 
Judd WW (1953). A Study of the population of insects emerging as adults from the Dundas Marsh, Hamilton, Ontario during 1948. Am Midl Nat 49(3):801-824.

Kafle G, Cotton M, Chaudhary JR, Pariyar H, Adhikari H, Bohora SB, Chaudhary UK, Ram A, Regmi B (2008). Status of and threats to waterbirds of Rupa Lake, Pokhara, Nepal. J Ecol 1(1/2):9-12.

Kloskowski J, Green AJ, Polak M, Bustamante J, Krogulec J (2009). Complementary use of natural and artificial wetlands by waterbirds wintering in Donana, Southwest Spain. Aquat Conserv: Mar Freshwat Ecosyst 19:815-826.

Kohli K (2006). Okhla Bird Sanctuary gets a breather. Infochange News \& Features. Assessed from http://infochangeindia.org/environment/features/okhla-bird-sanctuary-gets-a-breather.html on 20-4-2009.

Kulkarni GN (1997). Impact of industrial effluents on the hydrobiology of Tungbhadra river, Kumarrapatna, Karnatka. Univ. of Agriculture Sciences, Bangalore, India, PhD Diss.

Kumar A, Singh AK (2002). Ecology, conservation and management of the river Mayurakshi in Santhal Pargana (Jharkhand state) with special reference to effects of sewage pollution on abiotic and biotic potentials, 1-43 p. In: Kumar A (Ed.). Ecology and conservation of lakes, reservoirs and rivers. ABD publishers, Jaipur, India.

Linton S, Goulder R (2000). Botanical conservation value related to origin and management of ponds. Aquat Conserv: Mar Freshwat Ecosyst 10:77-91.

Manahan SE (1993). Fundamentals of environmental chemistry. $6^{\text {th }}$ Ed. Lewis publishers, Georgia, 844 p.

Mara D (1978). Sewage treatment in hot climates. John Wiley and Sons: Chichester, UK, $168 \mathrm{p}$.

McGaha YJ (1952). The limnological relations of insects to certain aquatic flowering plants. T Am Microsc Soc 71(4):355381.

Mitsch WJ, Gossenlink JG (2000). Wetlands. 3rd Ed. John Wiley and Sons, New York, 920 p.

O'meara TF, Marion WR, Myers OB, Hetrick WM (1982). Food habits of 3 bird species on phosphate mine settling ponds and natural wetlands. Proc of Annual Conf of Southeastern Assoc of Fish and Wildlife Agencies 36:515-526.

Paulus SL (1982). Feeding ecology of Gadwalls in Louisiana in winter. J Wildl Manage 46(1):71-79.

Raina V, Shah AR, Ahmed SR (1984). Pollution studies of river Jhelum-I: An assessment of Water Quality. Indian J Environ Health 26:187-201.

Ramachandra TV (2001). Restoration and management strategies of wetlands in developing countries. EGJ 15:1-15.

Ramsar Convention (1971). Convention on wetlands of international importance. In: Carp E (Ed.). International Waterfowl Research Bureau, Ramsar, Iran.
Rao MN, Dutta AK (1979). Waste water treatment. Oxford and ABH publishing Co., Kolkata, 338 p.

Rooke JB (1986b). Seasonal aspects of the invertebrate fauna of three species of plants and rock surfaces in a small stream. Hydrobiologia 134:81-87.

Scotland MB (1940). Review and summary of studies of insects associated with Lemna minor. JNY Entomol Soc 48:319333.

Shannon CE, Weaver W (1949). The mathematical theory of communication. University Illinois Press, Urbana, $117 \mathrm{p}$.

Shrivastava VS, Patil PR (2002). Tapti river water pollution by industrial wastes: a statistical approach. Nat Env Poll Tech 1:279-283.

Sivasubramanium R (1999). Water quality of river Periyar (River Suruliyar) in Tamil Nadu. In: Mishra SR (Ed.). Limnological Research in India. Daya publishing house, Delhi.

Squires JR, Anderson SH (1995). Trumpeter Swan (Cygnus buccinator): food habits in the Greater Yellowstone Ecosystem. Am Midl Nat 133(2):274-282.

Standard methods for examination of water and wastewater (APHA) (2005). 21 $1^{\text {st }}$ Ed. American Public Health Association, Washington D.C, 1368 p.

Stewart RE Jr (2001). Technical Aspects of Wetlands: Wetlands as Bird Habitats. National Water Summery on Wetland Resources, United States Geological Survey Water Supply Paper 2425. Assessed from http://water.usgs.gov/nwsum/ WSP2425/birdhabitat.html on 12-3-2009.

Tarzwell CM (1957). Water quality criteria for aquatic life in biological problems in water pollution, U.S. Department of Health, education and welfare, P.H.S 246-272.

Turner RK, van den Bergh JCJM, Soderqvist T, Barendregt A, van der Straaten J, Maltby E, van Ierland EC (2000). Ecological-economic analysis of wetlands: scientific integration for management and policy. Ecol Econ 35(1):7-23.

Urfi AJ (2003). The birds of Okhla Bird Sanctuary, Delhi, India. Forktail 19:39-50.

Van Geest GJ, Coops H, Roijackers RMM, Buijse AD, Scheffer M (2005). Succession of Aquatic vegetation driven by reduced water level fluctuations in floodplain lakes. J Appl Ecol 42:251-260.

Vijayan VS (1991). Keoladeo National Park Ecology Study: 1980-1990. Bombay Natural History Society, Mumbai.

Weller MW (1999). Wetland Birds: Habitat Resources and Conservation Implications. Cambridge University Press, $271 \mathrm{p}$. 